How to cite this article: Rodrigues, J., Santos, A. C., \& Teles, N. (2018). Financialisation of pensions in semi-peripheral Portugal. Global Social Policy, 18(2), 189-209. https://doi.org/10.1177/1468018117742826

\title{
Financialisation of pensions in semi-peripheral Portugal
}

\author{
João Rodrigues, Ana C. Santos and Nuno Teles \\ University of Coimbra, Portugal
}

\begin{abstract}
This article aims at contributing to the literature on the financialisation of pensions in Europe by examining the transformations occurring in semi-peripheral Portugal. The Portuguese case accounts for the variegated nature of financialisation in general, and of pension provision in particular, throughout Europe. While the country followed similar processes to those of core European Union (EU) countries, leading to an increasingly integrated financial sector in the international arena, this integration was mainly led by the banking sector rather than by capital markets. This helps account for the relatively reduced role of private retirement income products in the country. Nonetheless, the Portuguese pension system has been equally subject to reform, aiming at reducing its weight in public expenditure. The result is a contraction in coverage and benefit without achieving an equivalent match in supplementary private forms of pension provision. Under a prolonged period of stagnation and crisis, the deterioration of State pensions for the majority continues while a residual private, outward-oriented and foreign-owned pension sector grows for the most affluent, further exposing the systemic and variegated nature of financialisation processes in the semi-periphery.
\end{abstract}

\section{Keywords}

EU, financialisation, pensions, Portugal, semi-periphery, variegation

\section{Introduction}

Faced with the pressure that ageing populations represent to the sustainability of pension systems, and strongly influenced by international institutions, where the European Union (EU) plays a paramount role, all European countries have implemented reforms seeking

\section{Corresponding author:}

Ana C Santos, Centre for Social Studies (CES), University of Coimbra, Colegio de S. Jeronimo, Apartado 3087, 3000-995 Coimbra, Portugal.

Email: anacsantos@ces.uc.pt 
to control public expenditure on pensions and to boost financial markets (Dixon and Sorsa, 2009; Ebbinghaus, 2015). This has implied cuts in State pay-as-you-go (PAYGO) and Defined Benefit (DB) pensions and the promotion of prefunded capitalised forms of private pensions, resulting in increased personal responsibility for old-age security. Massive pools of retirement savings have been collected and channelled to financial institutions such as pension funds, mutual funds, banks and insurance companies, fuel-ling the expansion of financial markets over the past three decades. Life insurance and pension funds have steadily grown in all European countries, exposing the global nature of these reforms despite their different points of departure (see Table 2 in Appendix 1).

The scale of pension reform in the EU, in depth and extension, brings to the fore insti-tutional variegation in pension provisioning. This variegation has three sources. The first is born out of national politically contested historical processes underpinning the crea-tion and maturation of each system, involving unique configurations of state involve-ment and employers-employees arrangements (Dixon and Monk, 2009; Dixon and Sorsa, 2009). The second is associated with regressive reforms in public pension schemes and the recent growth of new capitalised retirement income institutions (Blackburn, 2003; Clark, 2000). These have been led by the financialised restructuring of global capi-talism, having variegated impacts on the different systems. Closely related to the latter, the third emerges from the variegated impacts of the Global Financial Crisis (GFC). In this more recent global context, commonly held distinctions between State and private pension provision have broken down, considering, on one hand, State support to private schemes, and, on the other hand, the nationalisation or reversion of private pension funds (Clark and Whiteside, 2003; Ebbinghaus and Whiteside, 2012). In the aftermath of the GFC, pension policy is both a social question and a financial one in that it affects the position of an important segment of the financial sector that drove capitalism in the recent decades (Ebbinghaus et al., 2012: 241). And, both questions raise fundamental issues at both the individual - relating to the ability to secure sufficient retiree income - and aggregate levels - relating to its detrimental impacts on economic growth and thereby on the sustainability of both the public and private components of the pension system (Casey, 2012).

This article aims at contributing to the literature on the financialisation of pensions by examining those transformations as they were occurring in semi-peripheral Portugal. This means that this article will approach pensions within the framework of the studies on financialisation (Lapavitsas, 2013; Rodrigues et al., 2016). In this context, the Portuguese case is deemed particularly illuminating for at least two-related reasons.

First, it provides evidence for the idea that variegation in pension systems is driven by the variegated nature of financialisation itself, insofar as 'the extent and influence of financialisation across the various elements of economic and social reproduction are highly contingent, reinforcing the variegated nature of outcomes' (Fine and Saad-Filho, 2016: 12). The Portuguese case provides evidence for the idea that 'variegated financiali-sation' must take into account the differentiated ways in which finance interacts with particular economic sectors and social provisioning within each country, that is, the financialisation of particular systems of provision (Bayliss et al., 2013). Study of the impact of finance on pension systems is then required, accounting for its specific nature, its structures, agents, processes and relations that characterise the entire chain of 
provision, which is also shaped by multiple social, political, geographical and historical factors. More concretely, the links between processes of financialisation and processes of privatisation in pension provision vary in their intensity. In Portugal, as shown below, financialisation, with its national specificities, has not led to an automatic development of private schemes capable of directly challenging the dominant paradigm of public provision.

Second, by focusing on a semi-peripheral country belonging to the EU, the Portuguese case underlines the relevance of its relative position within the global economy, both illuminating the role of international institutions in the reforms pursued in the pension system and the way financial agents operating on a global scale shape the trajectory of a particular country. The impact of the GFC in a stagnated and dependent economy such as Portugal was severe, with particular impacts in its pension system.

Accounting for the specific trajectory of the Portuguese pension system helps explain why it remains by and large in the public domain and is being financialised by stealth, where domestic capital markets still have a relatively limited role not least because they lack the prefunded retirement arrangements that helped spur financial markets in Anglo American countries (Clark, 2000; Toporowski, 2000). Nonetheless, a large segment of the population is (and a larger one will soon be) excluded from a decent income in old age, on one hand, and the country is (and will be further) exposed to capital outflows, on the other hand.

The article is organised as follows. Section 'Variegated financialisation of pensions in Europe' starts off with an overview of the financialisation of pensions in Europe, highlighting the variegated nature of pension systems. Section 'The role of the EU in the financialisation of pensions in Europe' highlights the role of the EU in promoting the financialisation of pensions, which is particularly relevant to semi-peripheral European contexts. The Portuguese case is subsequently examined. To set the overall context, sec-tion 'The semi-peripheral nature of financialisation in Portugal' briefly presents the semiperipheral nature of financialisation in Portugal and section 'The financialisation of pensions in semi-peripheral Portugal' then examines the institutional change and the gradual financialisation of pension provision. Section 'Conclusion' concludes the article highlighting the complex and context-specific intertwining of finance with pensions.

\section{Variegated financialisation of pensions in Europe}

Pension provision in Europe is variegated. Each system involves a particular mix of State, employers-workers arrangements and individualised forms of insuring income after retirement. Different forms and combinations of provision for retirement income abound, with different degrees of public and private involvement, including noncontributory universal social assistance benefits for retirees excluded from other arrangements, PAYGO schemes, earnings-related DB plans, Occupational DB pen-sion funds and Defined Contribution (DC) prefunded pension plans, among others. Such variety poses significant intellectual and policy challenges when trying to iden-tify commonalities among national systems, or when trying to assess the impact of systemic trends such as those related to recent pension reforms and the role of the EU in its unfolding. 
Pension provision in Europe is also variegated due to the different degrees to which the national social security systems have been intertwined with finance. This is a devel-opment that by and large results from reforms of pension systems in Europe that have reduced the size of the non-funded component of pensions and promoted new capitalised retirement income institutions. The role of the relative development of financial markets in marking variation in pension provision in Europe has already been scrutinised (e.g. Dixon and Monk, 2009; Dixon and Sorsa, 2009; Ebbinghaus, 2011, 2015), leading to what could be labelled as the 'variegated financialisation' of pensions. Such financialised nature of pension provision makes it even more challenging to assess the impacts of the reforms on convergence or divergence processes across European pension systems.

Comparative exercises in political economy and public policy, in dialogue with the Varieties of Capitalism (VoC) approach (Hall and Soskice, 2001), expose the hybrid and context-specific nature of pension systems, thus undermining clear-cut contrasts and leading to more careful empirical accounts of specific national trajectories (Clark and Wójcik, 2007). While the category of Liberal Market Economies (LME) can be associ-ated with the Anglophone world, and that of Coordinated Market Economies (CME) with Continental and Nordic Europe, it is hard to fit any given case within a rigid ideal-type. Ebbinghaus (2015) finds a high correlation between financial markets and funded pensions in liberal Britain, that pension fund assets in Germany's coordinated market-economy are still relatively small, and that Southern and Eastern European countries are laggards in pension fund asset growth. But, he also finds increased variation that does not fit the VoC taxonomy:

[T] he Netherlands and Switzerland . . . two 'liberal' CMEs outperform the United Kingdom in pension assets, as substantial investments are made by the Dutch collectively negotiated and the Swiss mandatory pension funds. Moreover, the Nordic CMEs now also have substantial funded pillars as part of public or private pensions. But there remains a wide variation, including funded elements as part of mandatory public pensions (Sweden), mandated, partly funded occupational pensions (Finland), negotiated occupational pensions (Denmark), and Norway's oil-financed global government pension fund. (Ebbinghaus, 2015: 63)1

Analyses attentive to the specificities of the national systems, that is, to what differentiates them rather than to what makes them similar, have begun to pay closer attention to the variegated nature of pension systems. In their comparative work, Dixon and Monk (2009) show how changes in global finance, such as those relating to accounting standardisation procedures, have had differentiated impacts, even in countries with highly financialised pension systems such as the Dutch and the British, taken as 'progenitors of pension fund capitalism, with massive pools of capital chasing returns and financial prospects across the globe' (p. 635). Although these systems have had a strong reliance on funded occupational DB schemes within the EU context, and while accounting practices have led to significant transformations in these schemes, the resulting changes differed considerably. Being under pressure since the Thatcher Governments, the United Kingdom has seen a massive decline in occupational DB pensions, leaving many uncovered, as this decline has not been met with increased provision of other occupational pension instruments. In 2007, DC plans had the same number of members that they had in 1991, thus meaning that a rising cohort of workers 
did not have any pension plan for retirement other than the basic State pension. In contrast, and exposing social solidarities and historically contingent institutional settings (e.g. mandatory participation in occupational funds via collective contracts, employees' and employers' equal representation rights on the boards of firms, resistant unions), the reform of the Dutch occupational pensions has been able to maintain coverage and overall collective sharing of risk. Dixon and Monk (2009) then conclude '[i] nstead of convergent outcomes, we are faced with limitless possibilities of hybridization and simultaneously occurring convergence and divergence' and thus '[p]olitical economies remain institutionally distinct regardless of increasing amounts of financialisation' (p. 635). Similarly, comparative analysis of the Finnish, French and German pension systems seen against the backdrop of financialisation revealed that recent transformations in retirement income arrangements are 'conditioned by frameworks quite typical [ . . . of] the particular political economies', as these transformations 'remain strongly embedded in and steered by the regulative, normative and discursive institutional environments of each political economy in question' (Dixon and Sorsa, 2009: 360-361). Similarly, and now focusing on pension reforms in France and the United Kingdom, Lagoutte and Reimat (2013: 328-329) conclude that these 'are not only founded on a specific approach to pension systems [ . . ] but even more so on the existing institutional arrangements'. In their view, 'the French pension system remains focused on preserving a high level of protection for its core workers' and 'the British system upholds high labour market flexibility and strengthens pension funds to pre-serve financial market performance'. However, they also found that 'both systems have reinforced the role played by means-tested benefits and minimum pensions for lower-income groups, stressing their [intrinsic] contradictions'.

The Portuguese case offers a contrasting example to the above-mentioned countries. In addition to a process of financialisation with its own characteristics, the Portuguese system of pension provision has also followed a peculiar trajectory that sets it apart from other experiences. One characteristic trait is the relatively recent construction of the social security system after the 1974 democratic revolution. If, on one hand, Portugal followed processes of economic and financial liberalisation and privatisation since the mid-1980s, on the other hand, these were carried out while the Portuguese Welfare State was still being built. Since the late 1980s, these processes were carried out without apparent contradiction, as the former did not affect the development of the latter, particu-larly until the adhesion to the Euro. On the contrary, the convergence and integration of the Portuguese financial sector with its Western European counterparts allowed for a growing inflow of foreign capital - mainly in the form of debt - that spurred economic growth and supplied fiscal income needed to fund its infant Welfare State.

These developments are associated with the insertion of the Portuguese political economy into the international economy, not least through entry into the European Economic Community (EEC) in 1986, and subsequent participation in the Economic and Monetary Union (EMU) in 1999. This has marked the semi-peripheral position of the country within the world economy, which combines features of the centre - such as the common currency, the Euro - and also features normally present in peripheral countries - such as foreign capital dependence and bank hegemony in the financial sector (Rodrigues et al., 2016). 
The rise of the private sector in pension provision has been gradual, fundamentally done by stealth, remaining relatively marginal within the universal public system of the country. Public pension provision is thus still fairly independent from the operation of financial agents and markets. To understand the peculiar mode and tempo of this process, the role of the $\mathrm{EU}$ in the promotion and shaping of recent reforms of pension provision in Europe has to be scrutinised.

\section{The role of the EU in the financialisation of pensions in Europe}

Pension reform is part and parcel of a broader neoliberal agenda that has involved global policy actors in their development, transfer and implementation, both in advanced capi-talist countries and in the developing world (Orenstein, 2005). The entrenched variega-tion of pension systems at the national level has not stopped this ideational trend towards homogenisation.

International organisations have been active in promoting pension reform in many countries. The World Bank (WB) and the Organisation for Economic Cooperation and Development (OECD) had a leading role in launching the policy agenda on the reform of public pension systems. They sought to address the, apparently uniform, pressure an ageing population constitutes on the sustainability of pension provision, underlining the imperative of controlling public spending on pensions, and the need to promote financial markets to boost economic growth, especially in less developed countries (OECD, 1996; World Bank, 1994).

Two different strategies have been pursued. Parametric reforms have focused on the formulae of public pensions, fostering a tighter link between contributions paid and pen-sion income, and on the conditions of access, raising minimum retirement age and con-tribution years, resulting in a substantial reduction in pension value and coverage. More radical reforms have aimed at substituting the collectively based DB pensions for indi-vidualised and private DC schemes (OECD, 2005). As the latter involve high transition costs for public finances and face fiercer political opposition, parametric reforms have been more widespread. In either case, these reforms have successfully achieved the main target of reducing public expenditure as conveyed by a general decrease in gross replace-ment rate (i.e. the percentage of retirement income to previous wage) in most OECD countries, with some countries expecting sharp drops (more than 25\%), particularly affecting the poor and women (OECD, 2007).

At the European level, the European Commission (EC), albeit seemingly lacking policy instruments to directly intervene in each member's social realm, has had an indi-rect, but influential, role in promoting and shaping reforms of pension provision. These reforms have been framed in terms of the need to meet the challenges of an ageing soci-ety and securing long-term sustainability of pension systems, advocating for the devel-opment of private schemes to complement or partially replace public pension provision as a favoured alternative to parametric reforms (EC, 2006). A critical aspect in European political strategy was the setting up of the so-called 'Open Method of Co-ordination' (OMC) on pensions in 2001. Replicating the strategy already in use for labour market reform, this method involves setting common objectives, converting them into national 
policy strategies and monitoring pension reform periodically on the basis of commonly agreed and defined criteria. In 2006, and based on the national strategy reports, the EC (2006) already applauded the 'substantial progress in reforming pension systems since the 2003 Joint Report' (p. 11). Besides the control of public expenditure through 'parametric' reforms - lengthening working lives and strengthening the link between contributions and benefits - the 2006 report also advocated private schemes to complement or partially replace public pension provision as a favoured alternative. More recently, the EC (2012) once again praised ongoing reform efforts, deemed effective to the extent that 'public pension schemes have become much more able to withstand the pressures of population ageing' (p. 13). Despite the focus on future sustainability, this new European interference on a policy area previously thought of as the prerogative of Member States should be understood against the backdrop of the European Monetary Union (EMU). Social spending has become under fiscal pressure imposed by the 'Stability Pact', mostly associated with the wider strictures of the Euro.

Renewed concerns about the future sustainability of occupational pensions have emerged after the GFC (Casey, 2012), not surprisingly related again to EMU policy. The most significant pertain to the recent drop in interest rates to near zero values with slim immediate prospects for recovery due to the adoption of expansionary monetary policy to tackle the financial and economic crises (e.g. through the European Central Bank quantitative easing operations). Moreover, prolonged international economic stagnation, labelled by many as 'secular' (Summers, 2013), has led to high volatility further pushing down returns in equity markets, compromising pension products' yields. These preoccupations have been voiced by the European Insurance and Occupational Pensions Authority (EIOPA, 2016) that forecasts deficits of about 22$25 \%$ in prefunded DB plans and a decline in pensions' gross replacement rates in DC plans of around $10-19 \% .2$

The GFC has revived criticisms that were already levelled against the financialisation of pensions in the wake of the 2001 'dot.com' financial crisis. Indeed, many of the detrimental consequences of the growing reliance on pension funds and the expansion of financial markets had already been identified at the time, implying that economic growth is the only robust answer to the sustainability of pension systems in the long run, whether public or private.3 Thus, the current GFC has exposed yet again 'the fragility of relying upon savings-based schemes to plug the "pension gap" that restraining public expenditure is likely to produce'. But, contrary to what could be expected, this failure 'has not reversed prevailing orientations that place greater emphasis on the individual rather than on the collectivity, and on the private rather than on the public' (Casey, 2012: 261).

To conclude, while pension reform has been a shared policy across Europe, and actively fostered by the EU, different countries have followed variegated paths. Convergence towards a common, financialised pension system is not forthcoming. This is even less so now as the financial and social weaknesses of a pension system reliant on capital markets are more evident in the aftermath of the GFC. Portugal, a semiperipheral country, reveals additional difficulties in a convergence towards private fund capitalism related to the general contours of broader financialisation processes that are briefly pre-sented in the next section. 


\section{The semi-peripheral nature of financialisation in Portugal}

The Portuguese economy and society has followed what has been conceptualised as a semi-peripheral type of financialisation (Rodrigues et al., 2016).4 This notion was forged to account for, on one hand, the intermediate position of the Portuguese economy in the world economy, that is, an industrialised country that is increasingly unable to compete with countries with which it is most closely integrated, and, on the other hand, the institutional features of its financial system, which shares characteristics of both core and peripheral countries, being mostly shaped by the process of European integration and by the predominance of loanable capital within the framework of the Euro. The concept of semi-peripheral financialisation in the Portuguese context thus underlines the more predominant and critical role of bank loanable capital in shaping recent changes in the economy and in society, as well as its role in intertwining international finance with Portuguese economic agents, similar to other peripheral and semi-peripheral contexts (e.g. Lapavitsas, 2013).

Portugal is thus a semi-peripheral country within the world economy, being marked by late industrialisation and lasting backward economic development relative to the core Northern and Central European countries. With a colonial past, and decolonisation occurring as late as the mid-to-late 1970s, the country rapidly geared itself towards integration in the then EEC, formalised in 1986. Portugal's laggard position has reinforced the role of the EU in driving financialisation in the country. Participation in the EEC accelerated reforms in many financial and non-financial sectors, and participation in the EMU, in particular, brought unprecedentedly advantageous financial conditions, such as almost unlimited access to hard currency and loanable capital at low interest rates, a feature often unavailable to countries with similar levels of development.

The financialisation of the Portuguese economy and society was a rapid, but effective, process of socioeconomic transformation. Within the time-span of a mere decade, between the mid-1980s and the mid-1990s, the Portuguese financial system evolved from a State-controlled and 'repressed' financial regime to become a fully liberalised one, and well inserted into international circuits of finance. Despite the speed of these transformations, the transition was smooth without the financial instability that fre-quently accompanies such processes. The Portuguese case is even more remarkable when considering the scope and depth of these transformations.

The combination of two International Monetary Fund's (IMF) interventions (in 1979 and in 1983-1985) and the preparation for accession to the EEC set a favourable context for what has been uncritically labelled as the 'modernisation' of the Portuguese financial system from the mid-1980s onwards. The privatisation and liberalisation of the financial sector, which put an end to credit limits and administrative interest rates, was the first set of reforms. A second set of reforms was linked to the release of compulsory reserves deposited in the Bank of Portugal, which were subsequently transformed into public debt, gradually securitised and traded on secondary markets, and open to foreign investors.

Accession to the EEC, and ensuing integration in the European single market for goods and services, implied liberalisation and harmonisation with the different segments and practices in the European banking sector, putting an end to the distinction between 
investment and commercial banking, abolishing restrictions on the entry of new agents, and aligning prudential requirements for the sector with the 1989 Basel Accords. The removal of all national controls over the international circulation of capital was the culmination of the process of transformation of the financial sector. In the 1990s, the coun-try adhered to the European Monetary System and the Exchange Rate Mechanism. With the active participation of the State, this trajectory illustrates an active political commit-ment to a process of integration increasingly guided by market forces and, in particular, by finance.

The processes of bank privatisation and financial liberalisation, basically completed in the early 1990s, and the nominal convergence trajectory culminating in adherence to the Euro, were decisive factors in transforming the Portuguese economy into a financial-ised one. Indeed, the official justifications and optimistic evaluations that underpinned the strategy for joining the Euro explicitly underline the aim of expanding the financial sector, perceived as being in the vanguard of 'modernisation'. The remarkable decrease of real interest rates was then seen as the most relevant sign of the successful insertion of national finance in international financial markets. The expectation was, on one hand, that it would allow firms to accelerate capital accumulation, taken as a pre-condition for future increases in overall productivity, and, on the other hand, that it would favour the accumulation of wealth by households, particularly through the purchase of housing stock.

The context-specific nature of the semi-peripheral financialisation of Portugal in turn led to the predominance of loanable capital from external sources and capital accumula-tion geared towards domestic non-tradable sectors, resulting in high levels of external debt and prolonged economic stagnation even before the crisis. Notwithstanding these peculiarities, there were also processes of convergence, particularly in household debt. Indeed, in Portugal, household debt grew from 35\% of disposable household income in 1995 to reach its highest value of $131 \%$ in 2009 . This means that from indebtedness levels below the European average in the mid-1990s, Portuguese households and firms were now near the top in the first decade of the Euro, with levels similar to the most financialised countries in the world (Rodrigues et al., 2016).

The newly privatised banks were the major source of loanable capital that was directed towards the private provisioning of housing, both on the demand side (loans to house-holds) and on the supply side (loans to the construction sector). The entrenched business model of the banking sector, where commercial banks prevailed vis-à-vis investment ones, underpinned financial expansion without a concomitant growth of financial securi-ties markets (stocks, bonds or derivatives). This is related, as will be seen below, with the meagre development of private financialised pensions.

Notwithstanding its relatively backward position within the EU in the 1980s, Portugal was able to articulate and make compatible the continuous development of social protection with policies of privatisation and liberalisation of the economy. This is partly explained by an enduring consensus among key political actors on the need to build the Portuguese Welfare State, an inheritance of the 1974 democratic revolution, and the affirmation of social rights (and corresponding obligations by the state) in the 1976 Constitution. At the time, state intervention was seen as instrumental to assure a certain degree of social and political legitimacy through the maintenance of high levels of 
employment and the consolidation of social protection (Fishman, 2010). European integration also helped in this regard, at least initially, by making convergence with more mature social welfare models a more salient focal point in public debates, and through access to European structural funds and the lowering of interest rates for foreign credit, which helped reduce the fiscal burden of public investment (Rhodes, 2002). The increase in real wages, aligned with the evolution of productivity levels, and the strengthening of safety nets clearly convey the political refusal to pursue a strategy of social devaluation. Departing from extremely low levels of social protection, and benefiting from particu-larly favourable domestic and external circumstances, the development of social protec-tion was therefore possible, even compatible with, legitimating the ongoing and speedy processes of privatisation and liberalisation of the economy.

However, in the new millennium, the country began a long process of stagnation with increasing levels of unemployment and the slow erosion of social provision. The GFC of 2007-2008 and its particular impact on the Southern part of the Eurozone accelerated these trends, ultimately revealing the incompatibility between ongoing financialised socioeconomic restructuring and social progress. The evolution of the Portuguese system of pension provision illustrates these trends well both before and after the Euro, the point to which we now turn.

\section{The financialisation of pensions in semi-peripheral Portugal}

In 1984, 10 years after the democratic revolution, following article 63 of the Constitution, and several legislative initiatives, Social Security had its formal founding moment with the Law on Social Security, which expressed the ongoing democratic consensus on effec-tive social rights. In terms of pensions, a democratic effort was made to institutionalise a public, mandatory protection system broadly based on the PAYGO rationale, which included a general scheme for workers in the private sector and a specific, slightly more generous, scheme for public sector workers known as the 'Caixa Geral de Aposentações' (a public sector pension fund).

The law on Social Security instituted a three-tiered system for pensions. First, a non-contributory system (Sistema de Protecção Social de Cidadania) was formalised, covering disability, survivor and minimum pensions for people that had not made any contributions, thus aiming at poverty reduction. These were funded by transfers from the Portuguese Treasury, reflecting the political recognition of an unconditional social right in a country where most workers were not covered previously by any form of social security, either public or private. Second, a statutory contributory system (Sistema Previdencial) for all private sector workers, funded by the 'Social Contribution Tax' (TSU)5 paid by employers (now $23.75 \%$ of earnings) and employees (11\% of earnings), was also instituted, thus providing social insurance for old age. Third, a similar mandatory system for public sector workers was created (Caixa Geral de Aposentações), initially with better pension accrual rates to compensate for average lower wages at the time of its creation. Although still in existence, its conditions have converged with the private sector since 1993 and it has been closed to new entrants since 2006. This has meant that from then on new public sector workers have enrolled in Sistema Previdencial. 
The Portuguese Welfare State, in general, and the State pensions system, in particular, has thus known a relatively late institutionalisation, apparently going against the neolib-eral international trends predominant from the 1980s onwards. This belated construction of a Welfare State meant that in terms of State spending on social protection relative to gross domestic product (GDP), 'Portugal was two or three decades late in following a path which other European countries had pursued between 1960 and 1990' (Mendes and Albuquerque, 2014: 139). Hence, the development of social protection in Portugal can be understood as converging with the European context, in line with other countries in Southern Europe: Social Security expenditure as percentage of GDP rose from 7.3\% in 1986 (the year Portugal joined the EEC) to $12.3 \%$ on the eve of the financial crisis in 2007 , reaching $18.4 \%$ in 2015.6 The number of old-age pensioners in Portugal, about half a million in 1975, tripled by 2000 and quadrupled by 2013, reaching 2,036,116 in 2016.7 This evolution reflects the inclusion of a growing number of workers in the universal public system, as well as, although to a lesser extent, the demographic trends associated with an ageing population. It is therefore not surprising that spending on old-age pen-sions, which in 1975 amounted to $1.2 \%$ of GDP (comprising approximately $25 \%$ of expenditure on the social security system), rose to $3 \%$ of GDP in 1991, reaching 6\% in 2013 (exceeding $60 \%$ of total spending on social security), becoming $5.6 \%$ in 2015 , covering around 3 million paid pensions (which do not match the number of pensioners, who may accumulate more than one pension). 8 However, pensions have remained low: in $2016,90.4 \%$ of old-age pensioners of the general Social Security scheme received a pension below the national minimum wage, which was $€ 530.9$

Reflecting global policy trends mentioned above, a new consensus started to emerge in the 1990s around the need to deal with the growing weight of pensions on public expenditure. Despite the low level of pensions and the existence, until very recently, of a surplus of contributions, the system was seen as being threatened by demographic trends, fundamentally related to ageing, that needed to be addressed. Commitments to the EU, which increasingly stressed balanced budgets as the main objective of economic policy, also needed to be taken into account. Vieira da Silva (2014), the social security minister who took this argument furthest in pushing for the 2007 reforms, ended up acknowledg-ing that 'from the nineties onwards [ . . . ] changes in the rules for calculating pensions were based on restriction or, in other words, reducing pensions' (p. 372).

The alignment with international practices began with the constitution, in 1995, of a Committee charged with producing a 'White Paper' on the reform of social security targeting the sustainability of the system (Ministério do Trabalho e da Solidariedade [MTS], 1998). The recommendations were not consensual, including the institution of contribu-tion thresholds and, for incomes above five minimum salaries, a supplementary manda-tory pension under a DC funded scheme to be managed privately. However, these recommendations failed to be implemented due to opposition from the main trade unions, some social security experts and left-wing parties.

Nevertheless, the dominant framing of the debate, that is, the menacing unsustainabil-ity of social security, persisted. In 2000, a new Law on Social Security was approved which stressed the importance of creating a reserve fund financed by employment-related contributions and of encouraging (public or private) voluntary supplementary funded systems, and enunciated the principle that the calculations for pensions should consider 
contributions as a whole rather than the best 10 of the last 15 years. In 2002, a DecreeLaw implemented the latter proposal, considering a transition period from 2002 to 2016. This was a highly important parametric change designed to reduce the value of pensions and marked the beginning of the new millennium as a moment of change in the rationale of the pension system (Murteira, 2011). Another fundamental milestone was the 2007 reform culminating in a new Framework Law, which introduced the following altera-tions: inclusion of a 'sustainability factor' in pension formulae to account for increased life expectancy, anticipation of the full adoption of the whole contribution period, and inclusion of a 'Social Support Index' which only guaranteed the purchasing power of the lowest pensions, whereas the real value of the remainder began to depend on specific economic growth rates. The strategy was reinforced with the Troika adjustment pro-gramme, in 2011, when taxes on pensions were levied, even if affecting above average pensions more and taken as a temporary measure in light of the country's emergency financial condition.

As a result of the reforms of the last decade, Portugal is now one of the EU countries in which public spending on pensions is forecast to decrease between 2013 and 2060, from $13.8 \%$ to $13.1 \%$ of GDP (EC, 2015: 74). Of course, this implies a clear sacrifice in pensioners' well-being since the cut in public spending means a fall in the replacement rate at retirement for the public scheme from 57.5\% in 2013 to $30.7 \%$ in 2060 (EC, 2015: 93). Meanwhile, given the rise of life expectancy, retirement age has increased to 66 years and 3 months and is expected to reach 67 years in the near future. All workers who want to retire early suffer a penalty of $0.5 \%$ for each month of anticipation. All this in a coun-try where the annual average old-age pension was around $€ 5000$ in 2015.10

The reforms were clearly governed by financial criteria along the EU priorities for public finance, sacrificing the incomes of pensioners dependent on public provision and widening the gap between pensions and the incomes of working people ultimately end-ing the idea of the indirect salary that was one of the philosophical pillars of the system (Murteira, 2011, 2013).

Social security reform has been characterised by a gradual approach to retrenchment. Despite its uneven results, the political construction of the private pensions market was ambitious, at least initially. Since 1985 , governments have actively promoted private pensions within the broader effort towards the rapid modernisation of financial markets, as described above. The emergence of pension funds and life insurance in Portugal has, from the outset, accompanied financial liberalisation. Their existence was initially envis-aged in Decree-Law No. 325/85 and was at the time restricted to funds managed by insurance companies ('life insurance' branches). Its scope was quickly extended in 1986, with the opportunity to create pension fund management companies (Garcia, 2003). In 1989, pension savings plans (known as PPRs) and the associated retirement savings funds were created, promoted by the State via income and capital tax breaks.

The initial growth of these funds was remarkable. In just 2 years, between 1987 and 1988, 149 funds appeared. These consisted of the pension funds of large privatised companies, such as the telecommunication corporation Portugal Telecom and mostly of bank pension funds that held 57\% of all pension fund assets in 1998 (Pedras, 2000). The overwhelming majority were DB funds resulting from collective agreements with workers, which replicated the rationale of the PAYGO social security system. During the 1990s, 
pension funds grew exponentially to a total of around 10 billion euros in 1998 (12\% of GDP). Benefitting from overall economic growth, these funds were also favoured by the climate of financial euphoria in the second half of the 1990s, which boosted capitalisa-tion - the effective average annual rate of return in the 1990s was a handsome $8.5 \%$ (Pedras, 2000).

The growth of pension funds halted at the turn of the millennium, with a sharp fall after 2010. Nowadays, DB funds do not even reach $10 \%$ of GDP. This fall is primarily explained by the transfer of several bank DB funds to the public PAYGO social security system. In a context marked by economic stagnation, crisis in the capital markets and generalised reduction of workers in the sector, banks ultimately transferred their future (DBs) liabilities to the State, providing the latter with financial assets that enabled it to nominally reduce the budget deficit. This was a case of socialisation of expected future losses in exchange for one-off, but much needed, fiscal revenue necessary to comply with the strictures of the Growth and Stability Pact. As elsewhere, the government not only assisted the growth of private schemes but also rescued some of them in the end. And in so doing, it revealed the failure of private (DB) pension funds in the stagnated Portuguese context. Nevertheless, banks still remained the main holders of pensions funds, in particular the BCP (through the Pensõesgere fund), the Caixa Geral de Depósitos (CGD pensions) and BPI (Life insurance and pensions), where almost two-thirds of the market is concentrated largely replicating the current oligopoly in a banking sector now mostly foreign-owned (the exception being CGD, which remains in state hands; Instituto de Seguros de Portugal [ISP], 2013).

However, the decline of pension funds in Portugal does not imply a generalised decline in importance of individual savings products for retirement. In fact, there has been marked growth in PPRs provided by insurance companies. Unlike the aforementioned pension funds, these PPRs do not provide DBs but instead the total value of their financial application, capitalised over years. But they offer guaranteed capital and a min-imum return rate, which means that these products are actually investment funds with a low-risk profile. Moreover, they have benefited from significant tax concessions in the early stages, thus contributing to their implicit returns. The value of these PPRs has increased exponentially, from 2 billion to 12 billion euros between 1998 and 2013 (ISP, 2013). Overall, the net equity of households in life insurance and in pension fund reserves to GDP rose from $16 \%$ in 1995 to $42 \%$ in 2010 and declined since then to reach 35\% in 2012 (see Table 2 in Appendix 1).

Despite claims that pension funds are an efficient mechanism for mobilising and allocating capital, the growth of PPRs has resulted in a remarkable outflow of capital, particularly compared to other EU countries. In fact, in 2007, prior to the international financial crisis, $64.5 \%$ of insurance companies' investments in PPRs were applied in the EU, and only $14 \%$ were applied in Portugal (Table 1 below). Although this may be partly explained by the narrowness of the financial markets in a semi-peripheral economy such as Portugal (this extroverted profile is replicated, for example, in the Baltic countries), the negative effect on the growth of the Portuguese economy is undeniable, since these investments represent a transfer of financial resources to other countries. Although, investing abroad can be seen as a rational strategy from a microeconomic point of view, it generates deleterious macroeconomic consequences: in contributing towards lower 
Table 1. Geographical recipients of pension funds and life insurance savings products (ISP, 2007).

\begin{tabular}{lcc}
\hline & Life insurance (\%) & Pension funds (\%) \\
\hline Rest of the world & 13.6 & 5.3 \\
Off-shores & 7.6 & 5.2 \\
Portugal & 14.3 & 23.8 \\
Rest of the EU & 64.5 & 65.7 \\
\hline
\end{tabular}

EU: European Union.

economic growth rates, in a country where capital is scarce and investment low, higher unemployment rates and fewer contributions to the public system, it affects the sustainability of the system, feeding a never-ending negative circle.

Although the PPR market is almost an exclusive preserve of insurance companies, this reality should not disguise the influence of the banking sector given that the main insurance companies belong to major national banks. Fidelidade, the biggest insurance company with a $31 \%$ share of the market, belonged to Caixa Geral de Depósitos until it was privatised in 2014 and has since been controlled by Chinese capital (via Fosun). The second largest insurance company, Ocidental Seguros, with a $20 \%$ share of the market, belongs to BCP and the international insurance company Ageas. The companies ranked third and fourth belong to the former BES bank (Tranquilidade, nowadays controlled by the North American private equity fund Apollo) and the BPI bank (Allianz).

The financialisation of pensions in Portugal also comprises the increasing influence of finance on the public social security system. The Social Security Financial Stabilisation Fund (Fundo de Estabilização Financeira da Segurança Social [FEFSS]), created in 1989 to manage the surpluses of the PAYGO system, offers one example of this influ-ence. Like other European State-owned funds (Dixon, 2008), the FEFSS has also sought to copy the investment strategy of private funds. Its finances are the result of transferring $2-4 \%$ points of the percentage value of contributions from salaried workers, depending on the economic situation during the year in question, which may justify its temporary suspension, as was the case in 2004-2005 and 2012-2013 (Instituto de Gestão de Fundos de Capitalização da Segurança Social [IGFCSS], 2014: 5).

The FEFSS portfolio has expanded steadily over the past 20 years, and was equivalent to $7.1 \%$ of GDP in $2013 ; 66.0 \%$ of this portfolio was allocated to fixed income products (including Portuguese State debt); $16.0 \%$ to variable income applications, in particular European (28\%), North American (57\%) and Japanese (15\%) shares; $15.6 \%$ was applied in liquid funds; $1.6 \%$ in real estate; and $0.6 \%$ was channelled to the strategic reserve designed to promote the strategic interests of the Portuguese economy. The semi-periph-eral character of the Portuguese economy is again apparent with domestic capital being invested outside the country. The yield generated by the fund has been modest, although in line with other national and international funds, achieving an effective annual rate of $2 \%$ (IGFCSS, 2014). Nowadays, reflecting the public debt market crisis, this pattern has started to change. More recently national public debt has gained weight in the fund's portfolio. 
In Portugal, the financialisation of pensions has thus been marked by the erosion of public pensions and the (slow) growth of private ones. However, Portugal occupies a modest position within the EU in terms of the relative weight of life insurance products and pension funds to GDP (cf. Table 2 in Appendix 1). While Portuguese banks, the most important agents of the Portuguese financial system, have been promoting private pen-sions, their business model has been centred on getting access to foreign loanable capital to lend it to households and construction and real estate firms. Investment banking has therefore been relatively residual in their business model revealing the rather limited financial securities market in the country, as is typical of semi-peripheral countries. However, the expansion of a private savings market for old age remains limited. This is compounded with the fiscal costs of more radical reforms targeting the transition to man-datory private schemes, which would decrease the revenues of the public system without diminishing the financial commitments towards present and near future pensioners. Somewhat paradoxically, European fiscal rules themselves end up curbing the reforms envisaged for the semi-periphery given the huge costs of those reforms and the high levels of debt therein.

The scope for pension financialisation in Portugal is also constrained by demand side factors. Typically, financial markets cater to the most affluent, who have the capacity to save and invest. These social groups do not abound in semi-peripheral countries. In 2013, only $4.4 \%$ of Portuguese households belonging to the bottom quintile income group held voluntary private pensions and/or whole life insurance, whereas $42.1 \%$ of households belonging to the top decile hold this type of financial assets (Costa, 2016).

This situation is not likely to change in the near or far distant future. The EC (2015) forecast predicts that private retirement income products will remain limited in Portugal until 2060 (p. 82). Political resistance to further reform of the public system plays an important role too, but it is mostly the prolonged economic stagnation followed by deep financial and economic crises that constrain the expansion of private pension alternatives. With high levels of unemployment and low disposable household income, as well as a high level of household indebtedness, the majority of the population is dependent on a public system increasingly unable to provide an adequate retirement income. The semi-peripheral financialisation of Portuguese households becomes clear: while they follow those of most financialised countries in their high levels of debt, they are clear laggards in terms of holdings of financial assets.

\section{Conclusion}

Influenced by EU policy prescriptions and opportunities opened by liberalised financial sectors, European countries have reformed their pension systems of provision over the past two decades. The EU has been active in pushing pension reforms on its members, promoting private retirement income products perceived as an alternative for the increas-ingly eroded public systems. Notwithstanding institutional variegation across EU coun-tries, this policy orientation has produced the desired outcomes as life insurance and private pension funds have since grown in household balance sheets, and public expendi-ture on pensions has been tamed. 
In the wake of the GFC, alarms have sounded in pension fund markets. DB and DC funds are not exempt from sustainability problems as they are highly vulnerable to financial turmoil and equally dependent on economic growth. This means that PAYGO schemes may turn out to be a better option than private financialised pension funds for achieving the twin goals of sustainability and adequacy in pension provision. Being more insulated from financial instability, and involving distribution of income between work-ers and pensioners, PAYGO schemes can act as an aggregate demand stabiliser during economic downturns by ensuring greater stability of pensioners' income. And because they incorporate a distributive mechanism levelling out pensions across the socioeco-nomic strata, they reduce economic inequality in retirement having in turn a positive effect on long-term economic growth beneficial to PAYGO scheme sustainability (Casey, 2012; Cingano, 2014). Moreover, by relying on greater solidarity across generations and social strata, it curbs financial instability produced by the international financial flows driven by the top income echelons of the population in the search for yield, particularly during low interest rate environments such as the present one.

The Portuguese case reinforces the view that different national institutional configurations preclude any straightforward convergence at the European level with the Anglo American liberal market model. In Portugal, the construction and subsequent erosion of the State pension system has been accompanied by the slow growth of private pension schemes. Private-funded schemes play only a minor role in the Portuguese pensions system, with low levels of take-up and relatively mediocre returns. This is partly explained by the late development of the public pension system and the semiperipheral nature of the country with relatively immature securities markets and low levels of dis-posable household income. The gradual privatisation of the system has been relevant only for a small and wealthy segment of the household sector. In the aftermath of the GFC, there is little room for channelling meagre savings to capital markets while the State is financially drained and unable to sponsor such schemes on a large scale. Financial institutions, particularly insurance companies nowadays belonging to foreign capital, capture a small and lucrative market, which has become yet another mechanism for exporting capital to the European core. Exposing the semiperipheral condition of the country, the growth of finance in the Portuguese pension provision system faces severe obstacles pointing towards a different and more limited form of financial expansion, increasingly involving foreign financial institutions and targeting an ever more seg-mented market.

The Portuguese case thus provides evidence for variegated financialisation, that is, the systemic and variegated nature of the increasing dominance and influence of finance across nations. On one hand, Portugal has followed similar processes to those of core countries leading to an increasingly integrated financial sector in the international arena; on the other hand, this integration was mainly led by the banking sector rather than by financial markets. The Portuguese pension system also provides evidence for the idea that variegation in the financialisation of pensions adds an additional analytical scale to the examination of the differentiated ways in which finance interacts and shapes the economy and society. The relative underdevelopment of the private pension segment could not be understood without the context-specific trajectory of the Portuguese social security sys-tem, which blocked the expansion of this segment of financial asset markets. 
The Portuguese case also emphasises the role of the relative position of the country within the European political economy to account for the variegated nature of its financialisation. Notwithstanding the relative weakness of the Portuguese Welfare State, as well as the lower levels of wealth and income of Portuguese households, heavily pres-sured by EU economic and pension policies that targeted the control of public finances, the Portuguese pension system was subject to reform. Besides balanced budgets, the logic of reform can be found in the so-called internal devaluation, that is, in the effort, also led by the EU, to diminish social contributions as a way to reduce labour costs, par-ticularly in its semi-peripheries. The unintended result has been the gradual reduction of coverage and benefits without equivalent matching of supplementary private forms of pension provision. Particular socioeconomic groups, such as women who generally have shorter and lower paid working careers, will receive diminished and insufficient pen-sions resulting from the tightening of the link between contributions paid into the public system and benefits paid out. Thus, the Portuguese case accounts for both the differenti-ated and uneven nature of financialisation processes in general and of pensions in par-ticular, leading to deterioration of a most critical domain of social provision promoting financial markets increasingly dominated by foreign capital to the benefit of the most affluent, while leaving growing numbers without adequate protection.

\section{Acknowledgements}

We thank the comments of the audience at the IIPPE Annual Conference 2016 where a previous version of this article was presented. We are especially grateful to Maria Clara Murteira who has commented on various versions of this article. Any error or omission is our own responsibility.

\section{Funding}

The author(s) disclosed receipt of the following financial support for the research, authorship, and/ or publication of this article: The research leading to this article was part of the FESSUD project that received funding from the EU Seventh Framework Programme (FP7/2007-2013, grant no. 266800).

\section{Notes}

1. See also the relative high weight of household life insurance and pension funds of the Nordic countries in Table 2 of Appendix 1.

2. These tests only consider risks associated with pension fund returns and thus ignore the effects of financial shocks on employment and wages, which would further magnify retire-ment income losses due to a reduction in workers and employers' contributions.

3. The long-term effects of the life cycle of pension funds were then highlighted, including the phases of 'expansion', 'maturation' and 'retirement' or the 'winding up' of the fund (Engelen, 2003). While the initial phase corresponds to a period of asset price inflation, it is expected that the maturation and winding up phases will lead to lower returns, forcing riskier investment strategies. This means that returns of capital capable of beating eco-nomic growth in the long run can only be achieved if the primary distribution of income further tips in favour of capital. A fundamental contradiction then emerges: on one hand, if returns on capital are higher than economic growth (i.e. $\mathrm{r}>\mathrm{g}$, the formulae synthesised by Piketty, 2014), there is growing inequality, penalising current workers and future retir-ees; but, on the other hand, if returns on capital are lower than economic growth, there 
is no longer an advantage of private pensions in comparison with public pay-as-you-go (PAYGO) systems.

4. This section summarises the trajectory of the financialisation of the Portuguese economy presented by Rodrigues et al. (2016), which should be consulted for a more developed account of its specific manifestations in financial and non-financial sectors.

5. The 'Social Contribution Tax' also funds other social benefits, such as unemployment insurance.

6. http://www.pordata.pt/en/Portugal/Social+security+expenditure+as+percentage + of + GDP705 (accessed 9 October 2017).

7. http://www.pordata.pt/en/Portugal/Social+Security+pensions+total++survivors+pensioners+ + disability+pensioners++old+age+pensioners-96 (accessed 9 October 2017).

8. http://www.pordata.pt/en/Portugal/Social+Security+pensions + as + percentage + of + GDP + total +expenditure+and+by+type-942 (accessed 9 October 2017).

9. http://www.pordata.pt/en/DB/Portugal/Search+Environment/Table (accessed 9 October 2017).

10. http://www.pordata.pt/en/Portugal/Average+annual+Social+Security+pension+total++survi vors ++ disability + and + old + age-706 (accessed 9 October 2017).

\section{References}

Bayliss K, Fine B and Robertson M (2013) From financialisation to consumption: The system of provision approach applied to housing and water. FESSUD Working Paper Series, no. 2, 1 August. Available at: https://econpapers.repec.org/paper/feswpaper/wpaper02.htm.

Blackburn R (2003) Banking on Death, or, Investing in Life: The History and Future of Pensions. London: Verso Books.

Casey BH (2012) The implications of the economic crisis for pensions and pension policy in Europe. Global Social Policy 12(3): 246-265.

Cingano F (2014) Trends in income inequality and its impact on economic growth. OECD SEM Working Paper, no. 163, 9 December. Paris: OECD Publishing.

Clark GL (2000) Pension Fund Capitalism. Oxford: Oxford University Press.

Clark GL and Whiteside N (eds) (2003) Pension Security in the 21st Century: Redrawing the Public-private Debate. Oxford: Oxford University Press.

Clark GL and Wójcik D (2007) The Geography of Finance: Corporate Governance in the Global Marketplace. Oxford: Oxford University Press.

Costa S (2016) Situação financeira das famílias em Portugal: uma análise com base nos dados do ISFF 2013 [Household financial situation in Portugal: An analysis based on the ISFF 2013]. Revista De Estudos Económicos 2(4): 15-59.

Dixon A and Monk A (2009) The power of finance: Accounting harmonization's effect on pension provision. Journal of Economic Geography 9: 619-639.

Dixon A and Sorsa V (2009) Institutional change and the financialisation of pensions in Europe. Competition \& Change 13(4): 347-367.

Dixon AD (2008) The rise of pension fund capitalism in Europe: An unseen revolution? New Political Economy 13(3): 249-270.

Ebbinghaus B (2011) The Varieties of Pension Governance: Pension Privatization in Europe. Oxford: Oxford University Press.

Ebbinghaus B (2015) The privatization and marketization of pensions in Europe: A double transformation facing the crisis. European Policy Analysis 1(1): 56-73.

Ebbinghaus B and Whiteside N (2012) Shifting responsibilities in Western European pension sys-tems: What future for social models? Global Social Policy 12(3): 266-282. 
Ebbinghaus B, Orenstein MA and Whiteside N (2012) Governing pension fund capitalism in times of uncertainty. Global Social Policy 12(3): 241-245.

EC (2006) Adequate and Sustainable Pensions: Synthesis Report. Luxembourg City: Office for Official Publications of the European Communities.

EC (2012) The 2012 ageing report: Economic and budgetary projections for the 27 EU Member States (2010-2060). European Economy 2/2012. Luxembourg City: Office for Official Publications of the European Communities. Available at: http:/ec.europa.eu/economy_ finance/publications/european_economy/2012/pdf/ee-2012-2_en.pdf.

EC (2015) The 2015 ageing report: Economic and budgetary projections for the 28 EU Member States (2013-2060). European Economy 3/2015. Luxembourg City: Office for Official Publications of the European Communities. Available at: http://ec.europa.eu/economy_ finance/publications/european_economy/2015/pdf/ee3_en.pdf.

Engelen E (2003) The logic of funding European pension restructuring and the dangers of financialisation. Environment and Planning A 35: 1357-1372.

European Insurance and Occupational Pensions Authority (EIOPA) (2016) Iorps Stress Test Report 2015. Available at: https://eiopa.europa.eu/Publications/Surveys/EIOPA\%20IORPs\%20 Stress\%20Test\%20Report\%202015\%20bookmarks.pdf.

Fine B and Saad-Filho A (2016) Thirteen things you need to know about neoliberalism. Critical Sociology 43(4-5): 685-706.

Fishman R (2010) Rethinking the Iberian transformations: How democratization scenarios shaped labor market outcomes. Studies in Comparative International Development 45(3): 281-310.

Garcia MT (2003) Economia e gestão dos fundos de pensões [The economics and management of pension funds]. Lisbon: Vida Económica.

Hall P and Soskice D (ed.) (2001) Varieties of Capitalism: The Institutional Foundations of Comparative Advantage. Oxford: Oxford University Press.

Instituto de Gestão de Fundos de Capitalização da Segurança Social [IGFCSS] (2014) Relatório de gestão do fundo de estabilização financeira da segurança social 2013 [Report of manage-ment of the social security financial stabilisation fund 2013]. Lisbon: IGFCSS.

Instituto de Seguros de Portugal (ISP) (2007) Relatórios do sector segurador e dos fundos de pen-sõe [Report of the sector of insurance and pensions fund]. Lisbon: ISP. Available at: http:// www.asf.com.pt/.

Instituto de Seguros de Portugal (ISP) (2013) Relatórios do sector segurador e dos fundos de pen-sõe [Report of the sector of insurance and pensions fund]. Lisbon: ISP. Available at: http:// www.asf.com.pt/.

Lagoutte C and Reimat A (2013) Public or private orientation of pension systems in the light of the recent financial crisis. Review of Social Economy 71(3): 306-338.

Lapavitsas C (2013) Profiting without Production: How Finance Exploits Us All. London: Verso Books.

Mendes H and Albuquerque JL (2014) Segurança social: as pensões como retribuição do trabalho e como responsabilidade solidária [Social security: Pensions as labour retribution and solidarity responsibility]. In: Barata A and Carmo R (eds) Estado social: De todos para todos [Welfare State: From All to All]. Lisbon: Tinta da China, pp. 135-166.

Ministério do Trabalho e da Solidariedade (MTS) (1998) Livro Branco da Segurança Social: Uma sintese [White paper on social security: A synthesis]. Lisbon: MTS.

Murteira MC (2011) A Economia das pensões [The economics of pensions]. Coimbra: Angelus Novus.

Murteira MC (2013) La réforme des retraites par le Portugal en 2007: une reforme structurelle. Revue Française Des Affaires Sociales 3: 126-147. 
Orenstein MA (2005) The new pension reform as global policy. Global Social Policy 5(2):

$175-202$.

Organisation for Economic Cooperation and Development (OECD) (1996) Ageing in OECD coun-tries: A critical policy challenge. OECD Social Policy Studies, no. 20, 7 November. Paris: OECD Publishing.

Organisation for Economic Cooperation and Development (OECD) (2005) OECD Pensions Outlook 2005: Public Policies across OECD Countries. Paris: OECD Publishing.

Organisation for Economic Cooperation and Development (OECD) (2007) OECD Pensions Outlook 2007: Public Policies across OECD Countries. Paris: OECD Publishing.

Pedras R (2000) A gestão dos fundos de pensões em Portugal [The management of pension funds in Portugal]. Cadernos do Mercado de Valores Mobiliários, no. 8, August 2000, Lisbon: CMVM. Piketty

$\mathrm{T}$ (2014) Capital in the Twenty-first Century. Cambridge, MA: Harvard University Press.

Rhodes M (2002) Why EMU is - Or may be - Good for European welfare states. In: Dyson K (ed.) European States and the Euro. Oxford: Oxford University Press, pp. 305-333.

Rodrigues J, Santos AC and Teles N (2016) Semi-peripheral financialisation: The case of Portugal. Review of International Political Economy 23(3): 480-510.

Silva JV (2014) Maturação e convergência: a evolução da proteção social - notas prévias de reflexão [Maturation and convergence: The evolution of social protection-Preliminary notes for reflexion]. In: Alexandre F, Lanção P, Lains P, et al. (eds) A economia Portuguesa na União Europeia: 1986-2010 [The Portuguese economy in the European union 1986-2010]. Coimbra: Actual, pp. 371-375.

Summers L (2013) Why stagnation might prove to be the new normal. Financial Times, 15 December. Available at: https://www.ft.com/content/87cb15ea-5d1a-11e3-a558-00144feabdc0.

Toporowski J (2000) The End of Finance. London: Routledge.

World Bank (1994) Averting the Old Age Crisis: Policies to Protect the Old and Promote Growth. New York: Oxford University Press.

\section{Author biographies}

João Rodrigues is a Lecturer at the Faculty of Economics and a researcher at the Centre for Social Studies, both at the University of Coimbra, Portugal. His research interests range from the history of neoliberalism to the recent Eurocrisis. He has published on these topics in journals such as Cambridge Journal of Economics, Competition \& Change and New Political Economy.

Ana C. Santos is a Researcher at the Centre for Social Studies, University of Coimbra, Portugal. Her research interests include methodology, financialisation, household finance and housing. She has published on these topics in journals such as Journal of Economic Methodology, Cambridge Journal of Economics and New Political Economy.

Nuno Teles is a Researcher at the Centre for Social Studies, University of Coimbra, Portugal. His research interests range from financialisation studies to development economics. He is one of the authors of Crisis in the Eurozone, London: Verso (2012). 


\section{Appendix 1}

Table 2. Net equity of households in life insurance reserves and in pension funds reserves to GDP (Eurostat).

\begin{tabular}{|c|c|c|c|c|c|c|}
\hline & $1995(\%)$ & $2000(\%)$ & $2005(\%)$ & $2010(\%)$ & $2011(\%)$ & $2012(\%)$ \\
\hline Netherlands & 122.6 & 153.5 & 165.9 & 178.7 & 184.4 & 205.6 \\
\hline $\begin{array}{l}\text { United } \\
\text { Kingdom }\end{array}$ & 129.4 & 160.5 & 145.6 & 147.3 & 146.5 & 157.1 \\
\hline Denmark & 64.7 & 82.2 & 100.3 & 116.3 & 127.7 & 137.8 \\
\hline Ireland & & & 67.6 & 81.7 & 80.4 & 85.7 \\
\hline Sweden & 29.7 & 54.0 & 69.8 & 81.5 & 84.1 & 84.6 \\
\hline EU & & & & 70.6 & 71.0 & 74.9 \\
\hline France & 27.9 & 45.6 & 56.8 & 72.8 & 71.4 & 72.3 \\
\hline Belgium & 19.4 & 35.5 & 52.6 & 62.3 & 61.4 & 64.1 \\
\hline Germany & 35.3 & 46.3 & 55.0 & 63.0 & 62.2 & 63.9 \\
\hline Cyprus & 20.8 & 23.7 & 33.3 & 51.3 & 50.1 & 55.2 \\
\hline Italy & 14.9 & 23.5 & 35.8 & 38.9 & 38.4 & 39.5 \\
\hline Portugal & 16.0 & 25.6 & 34.4 & 42.2 & 34.3 & 35.0 \\
\hline Austria & 14.8 & 22.0 & 27.0 & 29.4 & 28.5 & 28.9 \\
\hline Malta & & & 15.4 & 18.7 & 23.2 & 24.6 \\
\hline Spain & 12.6 & 21.0 & 22.7 & 22.9 & 23.0 & 24.1 \\
\hline Poland & 0.5 & 2.3 & 13.2 & 21.2 & 19.7 & 22.2 \\
\hline Croatia & & & 6.5 & 15.4 & 16.9 & 20.6 \\
\hline Finland & 5.5 & 16.0 & 20.2 & 20.1 & 18.0 & 20.3 \\
\hline Luxembourg & & & & 17.0 & 16.5 & 16.8 \\
\hline Slovakia & 0.0 & 0.6 & 4.9 & 12.7 & 13.5 & 14.8 \\
\hline Czech Republic & 3.8 & 5.4 & 8.9 & 12.3 & 12.9 & 13.7 \\
\hline Estonia & 0.1 & 0.5 & 4.6 & 11.1 & 9.9 & 10.9 \\
\hline Slovenia & & & 5.7 & 10.0 & 9.9 & 10.5 \\
\hline Hungary & 1.6 & 6.4 & 13.3 & 21.4 & 9.9 & 9.9 \\
\hline Bulgaria & & 0.4 & 2.8 & 6.5 & 6.8 & 8.2 \\
\hline Lithuania & 0.3 & 0.4 & 1.6 & 5.2 & 5.4 & 6.1 \\
\hline Latvia & 0.1 & 0.2 & 1.1 & 5.6 & 5.4 & 5.7 \\
\hline Greece & 1.8 & 3.0 & 3.2 & 3.8 & 3.9 & 4.2 \\
\hline Romania & & 0.2 & 0.6 & 1.7 & 2.1 & 2.7 \\
\hline
\end{tabular}

GDP: gross domestic product; EU: European Union. 